\title{
Loğziensia
}

$\mathrm{Nr} 2$ (2018)

D0l: http://dx.doi.org/10.18778/2544-7238.02.06

Małgorzata Krajewska*

\section{Plastyczność ośrodkowego układu nerwowego a modele i mechanizmy poprawy sprawności językowych po udarze niedokrwiennym mózgu}

\author{
Plasticity Of Central Nervous System And Mechanisms \\ Of Improvement In Language Skills After Ischemic Stroke
}

\begin{abstract}
Słowa kluczowe: neuroplastyczność, afazja, udar niedokrwienny mózgu, mechanizmy poprawy sprawności językowych po udarze mózgu
\end{abstract}

Keywords: neuroplasticity, aphasia, ischemic stroke, mechanisms of language skills improvement after stroke

\section{Zjawisko neuroplastyczności poudarowej}

Wraz z rozwojem nowych technik i metod badawczych, między innymi z zakresu mikrobiologii molekularnej oraz neuroobrazowania, funkcjonujące przez długie lata stanowisko dotyczące morfologicznej niezmienności mózgu zostało obalone na rzecz wiedzy potwierdzającej jego plastyczne (czyli regeneracyjne) właściwości. Współcześnie przyjmuje się szeroką definicję plastyczności układu nerwowego (neuroplastyczności, ang. neuroplasticity, brain plasticity, cortical plasticity), która w neurobiologii definiowana jest jako immanentna właściwość układu nerwowego, zapewniająca zmienność, zdolność uczenia się i zapamiętywania, możliwości samonaprawy oraz adaptacji do warunków środowiska. Neuroplastyczność oznacza trwałe zmiany własności neuronów, zachodzące pod wpływem działania bodźców ze środowiska lub uszkodzenia układu nerwowego. Co ważne, dotyczy ona wszystkich pięter układu nerwowego [Pąchalska, Kaczmarek, Kropotov, 2014, s. 69].

* Studia Doktoranckie Wydziału Filologicznego Uniwersytetu Pedagogicznego w Krakowie, ul. Podchorążych 2, 30-084 Kraków; Kliniczny Oddział Neurologiczny z Oddziałem Udarowym 5. Wojskowego Szpitala Klinicznego z Polikliniką w Krakowie, ul. Wrocławska 1-3, 30-901 Kraków; e-mail: malgorzata.krajewska@interia.eu. 
Odwołując się do mechanizmów aktywizujących procesy regeneracyjne, badacze wyodrębniają sześć głównych typów plastyczności [Kossut, 2010; Panasiuk, 2014]:

1) plastyczność rozwojową,

2) plastyczność kompensacyjną (pouszkodzeniową),

3) plastyczność wywołaną wzmożonym doświadczeniem czuciowym lub ruchowym,

4) plastyczność związaną z uczeniem się i pamięcią,

5) plastyczność występującą przy powstawaniu uzależnień,

6) plastyczność patologiczną ${ }^{1}$.

W odróżnieniu do pierwszego typu - plastyczności rozwojowej, która warunkuje nabywanie mowy, to właśnie typ drugi - plastyczność kompensacyjna - może warunkować jej odbudowę. Odkrycie zjawiska plastyczności pouszkodzeniowej stało się nadzieją w procesie rehabilitacji pacjentów z różnymi uszkodzeniami w obrębie ośrodkowego układu nerwowego, w tym również w terapii chorych $\mathrm{z}$ afazją poudarową. Przykładem plastyczności kompensacyjnej dokonującej się w uszkodzonym mózgu jest między innymi właśnie plastyczność po udarze niedokrwiennym, która związana jest z reorganizacją strukturalną i funkcjonalną zachodzącą na skutek zaburzeń naczyniowych powodowanych nagłym zmniejszeniem lub zablokowaniem przepływu krwi w odpowiedniej tętnicy wewnątrzczaszkowej. Traktując udar niedokrwienny w kategorii czynnika patogennego, można powiedzieć, iż - oprócz aktywowania szeregu procesów o charakterze dezintegrującym - przyczynia się on również do wyzwolenia plastyczności kompensacyjnej, która, jako mechanizm adaptacyjny, jest właściwością wyłącznie mózgu uszkodzonego ${ }^{2}$.

W kontekście analizy częściowej lub całkowitej utraty sprawności językowych po udarze mózgu to właśnie plastyczność kompensacyjna, związana ze zdolnością kory mózgowej do tworzenia nowej sieci połączeń nerwowych, wydaje się mieć kluczowe znaczenie w procesie odzyskiwania zaburzonych funkcji. Ian $\mathrm{H}$. Robertson i Jaap M. Murre [1999] wykazali, że mózg, wykorzystując zróżnicowane mechanizmy, może bazować na zjawiskach naprawczych, takich jak restytucja i kompensacja, których celem jest przywrócenie w jak największym stopniu funkcji utraconych na skutek uszkodzenia ${ }^{3}$. O ile we wczesnym etapie zdrowienia podkreśla się

1 Według Jolanty Panasiuk [2014, s. 58]: „U podstaw wszystkich wymienionych rodzajów neuroplastyczności leży zmiana siły i liczby połączeń międzyneuronalnych”.

2 Bez względu na rodzaj uszkodzenia pojawienie się dowolnego czynnika patogennego w mózgu przyczynia się do zachwiania wewnętrznej równowagi organizmu, wyzwalając funkcjonujące równoczasowo antagonistyczne procesy: dezintegracyjne oraz kompensacyjne [Herzyk, 2005].

3 Cytując za Wiesławem Drozdowskim [2007, s. 10]: „Restytucja jest próbą odbudowy uszkodzonych obszarów i systemów neuropsychologicznych, podczas gdy kompensacja jest włączeniem w proces odnowy innego obwodu kompensującego uszkodzenie, często odległego od uszkodzonego ogniska". Restytucja dotyczy zmian plastycznych typowych dla zdrowienia samoistnego w fazie wczesnej i związana jest ze zmianą gęstości połączeń w uszkodzonym ognisku. Kompensacja polega na reorganizacji sąsiednich obwodów. 
dodatkowo szczególną rolę zmian czynnościowych w tkance nerwowej, o tyle możliwość odbudowy funkcjonalnych połączeń neuronalnych wiązana jest najczęściej ze specyficzną stymulacją [Drozdowski, 2007].

Jak podkreśla Małgorzata Kossut [2010, s. 297], w odróżnieniu od plastyczności zdrowego mózgu zmiany plastyczne w mózgu uszkodzonym zachodzą na tle różnorodnych procesów patologicznych, takich jak procesy zapalne, zaburzenia metaboliczne, degeneracja włókien, obrzęk, zjawisko apoptozy i nekrozy. W przypadku udaru niedokrwiennego patomechanizm uszkodzenia mózgu jest bardzo złożony i przebiega w postaci reakcji łańcuchowej [Rejdak, 2007, s. 8]. Wśród niekorzystnych zmian w krążeniu mózgowym powodowanych ostrym niedokrwieniem wskazuje się między innymi takie zjawiska, jak deficyt energetyczny i utrata kontroli nad metabolizmem, zakwaszenie tkanek i wzrost poziomu dwutlenku węgla, zespół podkradania śródczaszkowego (tj. przepływu krwi z ogniska niedokrwienia do obwodu na skutek rozszerzenia naczyń), zjawisko obustronnej depresji (czyli niedomogi krążenia w półkuli nieuszkodzonej), a także zaburzenia mikrokrążenia. Jako jeden z możliwych mechanizmów samonaprawczych traktuje się zjawisko krążenia obocznego, które wytwarza się dzięki istnieniu naczyń zdolnych do tworzenia nowych dróg przepływu krwi [Herzyk, 2005, s. 121]. Zasadniczo jednak jako główną przyczynę śmierci komórek nerwowych w udarze niedokrwiennym wskazuje się zmiany metaboliczne wywołane utratą substancji odżywczych - tlenu oraz glukozy. Nagłe zmniejszenie lub zablokowanie przepływu krwi w jednej z tętnic mózgowych uniemożliwia ich właściwy transport. Stopień uszkodzenia mózgu zależy od czasu trwania niedokrwienia oraz jego nasilenia [Litwin, Członkowska, 2014, s. 191]. Mimo że udar może spowodować duże uszkodzenia w ramach ośrodkowego układu nerwowego i stać się przyczyną głębokich zaburzeń językowych, to jednak, jak potwierdza praktyka kliniczna, nawet w dorosłej korze mózgowej istnieje możliwość naprawy zaburzonych funkcji - zarówno spontaniczna, jak i stymulowana rehabilitacją [zob. Kossut, 2005; Rymarczyk, Makowska, Pałka-Szafraniec, 2015]. Dowodów na to dostarczają bezpośrednie obserwacje pacjentów z afazją poudarową, u których z czasem dochodzi do zmniejszenia się deficytów neurologicznych, w tym objawów zaburzeń językowych. Duża dynamika i zmienność objawów zaznaczają się szczególnie wyraźnie we wczesnym etapie zdrowienia, w którym ogromną rolę odgrywają przede wszystkim czynniki neurodynamiczne związane z przejściowymi zakłóceniami neurologicznymi [zob. Krajewska, 2015; 2016/2017].

\section{Modele i mechanizmy poprawy sprawności językowych po udarze niedokrwiennym mózgu}

Mimo że od wielu lat prowadzone są badania poświęcone mechanizmom poprawy funkcji zaburzonych wskutek uszkodzenia mózgu, to jednak wciąż brakuje spójności 
w poglądach dotyczących poprawy w zakresie sprawności językowych [Pąchalska, 2011, s. 219]. Biorąc pod uwagę fakt, że zjawisko plastyczności przejawia się zarówno na poziomie neuroanatomicznym, funkcjonalnym, jak i behawioralnym, a co za tym idzie - warunkowane jest kolejno zmianami na poziomie komórkowym, zmianami związanymi z przeorganizowaniem pracy sieci neuronalnych, jak również przekształceniem zachowania się człowieka [zob. Robertson, Murre, 1999; Papathanasiou, 2003], współcześnie w literaturze przedmiotu wskazuje się zasadniczo na rolę trzech głównych modeli plastyczności, bazujących na koncepcji Grahama E. Powella [1981]. Każdy z tych modeli obejmuje szereg zasad tłumaczących potencjalne mechanizmy poprawy zaburzonych funkcji, w tym również funkcji językowych.

Tabela 1. Modele plastyczności mózgu według G.E. Powella

\begin{tabular}{|l|l|l|}
\hline \multicolumn{1}{|c|}{ Modele fizjologiczne } & \multicolumn{1}{c|}{ Modele strukturalne } & \multicolumn{1}{c|}{ Modele przetwarzania } \\
\hline Zasada diaschizy & Zasada rezerwy & $\begin{array}{l}\text { Zasada zastępstwa } \\
\text { funkcjonalnego }\end{array}$ \\
\hline Zasada regeneracji & Zasada poziomów reprezentacji & Zasada plastyczności \\
\hline $\begin{array}{l}\text { Zasada tworzenia pobocznych } \\
\text { wypustek }\end{array}$ & Zasada wielostronnej kontroli & Zasada zreorganizowania funkcji \\
\hline $\begin{array}{l}\text { Zasada tworzenia nowych złącz } \\
\text { nerwowych (synaps) }\end{array}$ & & \\
\hline
\end{tabular}

Źródło: opracowanie własne na podstawie Pąchalska, 2011.

Co ważne z perspektywy organizowania terapii logopedycznej pacjentów $\mathrm{z}$ afazją poudarową, oddziaływanie powyższych mechanizmów, warunkujących powrót zaburzonych funkcji, jest ściśle związane z etapem zdrowienia. Według Joanny Seniów, Macieja Krawczyka i Anny Członkowskiej [2007] w przypadku zdrowienia po udarze mózgu procesy adaptacyjne uruchamiane pod wpływem nabytego uszkodzenia mózgu opierają się przede wszystkim na:

[...] naturalnej reorganizacji czynnościowej, która może być wspierana przez specyficzne oddziaływanie biologiczne (np. farmakoterapię, przezczaszkową stymulację magnetyczną) oraz trening umiejętności, czyli powtarzanie określonych zachowań (np. fizjoterapię, terapię logopedyczną, neuropsychologiczną, zajęciową) [Seniów, Krawczyk, Członkowska, 2007, s. 275].

Zjawiskiem charakterystycznym dla wczesnej fazy udaru jest obserwowana bardzo często w praktyce klinicznej spontaniczna poprawa stanu zdrowia pacjentów, w tym również spontaniczna remisja objawów zaburzeń językowych. Jako główną przyczynę aktywacji tych samoistnych mechanizmów naprawczych wskazuje się najczęściej procesy zachodzące na poziomie neurofizjologicznym i neuroanatomicznym, a zatem związane z oddziaływaniem mechanizmów w ramach wspomnianych już modeli fizjologicznych. Szczególną rolę przypisuje się tu przede wszystkim wpływom tak zwanych czynników neurodynamicznych, doprowadzających do przejściowych zakłóceń 
w pracy mózgu i związanych najczęściej ze zmianami w przewodnictwie synaptycznym komórek lub wzmożonym stanem hamowania procesów nerwowych, przy równoczesnym braku trwałych uszkodzeń w obrębie ośrodkowego układu nerwowego [zob. Maruszewski, 1974; Panasiuk, 2014]. Powstałe w ich efekcie zmiany neurodynamiczne w obrębie ośrodkowego układu nerwowego obejmują obszary niedotknięte w sposób bezpośredni uszkodzeniem, ale sąsiadujące $\mathrm{z}$ nim lub powiązane $\mathrm{w}$ jednym układzie czynnościowym. Zmiany te mają charakter odwracalny, co oznacza, że mogą wycofywać się samoistnie lub pod wpływem zastosowanego leczenia, podobnie jak wywołane przez nie objawy. Katarzyna E. Polanowska [2016, s. 17] zauważa, że obserwowana dość często w pierwszych dobach hospitalizacji po udarze spektakularna poprawa w zakresie sprawności językowych pacjentów $\mathrm{z}$ afazją związana jest przede wszystkim z ustępowaniem takich przejściowych zakłóceń neurofizjologicznych, jak na przykład wycofywanie się diaschizy, reperfuzja (czyli przywrócenie krążenia krwi) niedokrwionych tkanek i przywrócenie funkcji okolic penumbry, zmniejszenie się obrzęku, normalizacja przemian biochemicznych. Warto w tym miejscu zwrócić szczególną uwagę na dwa z możliwych zjawisk wyodrębnionych przez autorkę, a mianowicie zjawisko diaschizy oraz istnienie strefy półcienia, czyli penumbry.

Wyróżniona w ramach modelu fizjologicznego plastyczności zasada diaschizy ${ }^{4}$ zakłada, że uszkodzenie w jednym obszarze mózgu może przyczynić się do wystąpienia tak zwanego szoku neuronalnego również w innych obszarach, co oznacza możliwość pojawienia się bezpośrednio po uszkodzeniu znacznego, ale czasowego i odwracalnego zaburzenia funkcji [zob. Panasiuk, 2014, s. 60]. Wtórny szok neuronalny może występować w okolicy pierwotnego ogniska udarowego lub w miejscu odległym. Mimo że diaschiza wciąż jawi się jako zagadnienie nie do końca wyjaśnione, to jednak w przypadku nagłego zachorowania udarowego jej podwójna rola - zarówno jako czynnika destabilizującego, jak i naprawczego - wydaje się znacząca [zob. Herzyk, 2005; Paradowski, Pawlik, 2005; Drozdowski, 2007]. W rezultacie bowiem udar mózgu - z definicji skutkujący objawami ogniskowymi, czyli zlokalizowanymi i specyficznymi - wyzwalając zjawisko diaschizy, może przyczynić się również do wystąpienia objawów ogólnomózgowych (nieswoistych), a także błędnie lokalizujących, które, mimo że sugerują uszkodzenie konkretnego obszaru zgodnie z paradygmatem kliniczno-anatomicznym, to jednak w rzeczywistości dotyczą uszkodzenia innego, często odległego miejsca [zob. Turowska-Kowalska, Nowacki, 2013]. W praktyce przysparza to wielu trudności, zwłaszcza jeżeli chodzi o diagnozowanie afazji przede wszystkim właśnie w tak zwanej ostrej i podostrej fazie udaru, kiedy to w obrazie zaburzeń językowych na plan pierwszy mogą wysuwać się objawy neurodynamiczne. Podjęcie próby zróżnicowania objawów afatycznych i pseudoafatycznych wymaga od logopedy potraktowania diagnozy wyłącznie w kategoriach procesu, a tym samym uwzględnienia konieczności obserwacji dynamiki

4 Po raz pierwszy zjawisko diaschizy zostało opisane w 1914 roku przez Constantina von Monakowa. 
stanu klinicznego chorego, jak również bieżącej kontroli i weryfikacji oceny logopedycznej.

Inny mechanizm powrotu zaburzonych funkcji, równie istotny we wczesnej fazie udaru, związany jest $\mathrm{z}$ istnieniem strefy półcienia (penumbry), czyli obszaru bezpośrednio otaczającego ognisko zawałowe, w którym nie doszło jeszcze do całkowitego obumarcia neuronów i który ma szansę na uratowanie. Obszar ten charakteryzują dynamiczne zmiany, powodowane $\mathrm{z}$ jednej strony zaburzeniami przepływu krwi, a z drugiej zaburzeniami procesów energetycznych [Drozdowski, 2007]. Przez wdrożenie szybkiego leczenia przyczynowego (czyli leczenia trombolitycznego), powstrzymującego postępujący proces niedokrwienny, obszar ten ma szansę na powrót do prawidłowego funkcjonowania. Na początku zachorowania jest on obecny nawet u $80 \%$ pacjentów, ale w ciągu pierwszych sześciu do dwunastu godzin od wystąpienia objawów odsetek ten zmniejsza się, doprowadzając przy braku szybkiej interwencji terapeutycznej do wytworzenia nieodwracalnego ogniska zawałowego [Wnuk, Słowik, 2016, s. 9]. W tym kontekście powszechnie funkcjonujące w środowisku medycznym określenie „czas to mózg” nabiera szczególnego znaczenia [zob. Książkiewicz, Gąsecki, 2004].

Zmiany indukowane w pierwszych dobach zachorowania samoistnymi mechanizmami naprawczymi sprawiają, że we wczesnej fazie zdrowienia udar mózgu jawi się przede wszystkim jako zjawisko dynamiczne. Mimo że aktualnie wśród badaczy wciąż nie ma jednoznacznej zgody co do możliwego maksymalnego czasu trwania spontanicznych procesów samonaprawczych, to jednak najczęściej wskazuje się wczesne stadium udaru (pierwsze trzy do sześciu miesięcy), a zwłaszcza fazę ostrą i podostrą (do około dwóch-trzech tygodni od zachorowania), jako okres najbardziej sprzyjający zaistnieniu zjawiska samoistnej poprawy. Równocześnie podkreśla się także fakt stopniowego zmniejszania się dynamiki procesów samonaprawczych wraz z upływem czasu od momentu zachorowania [Seniów, 2009; Pąchalska, 2011; Polanowska, 2016]. W procesie zdrowienia pacjentów po udarze mózgu po upływie okresu spontanicznej poprawy bardzo często opisuje się także występowanie tak zwanego okresu plateau, w którym pacjent nie uzyskuje już dalszej poprawy funkcjonalnej lub ulega ona znacznemu spowolnieniu. Najczęściej występuje on po upływie około sześciu miesięcy od momentu zachorowania [Pąchalska, 2008, s. 70]. Aktualnie trudne wydaje się jednak znalezienie jednoznacznych dowodów potwierdzających tego typu regułę u wszystkich pacjentów $\mathrm{z}$ afazją poudarową. Jak bowiem pokazuje praktyka kliniczna, przebieg procesu zdrowienia jest zazwyczaj u każdego chorego silnie zindywidualizowany. Nie można ponadto wykluczyć również roli wielu innych czynników wpływających na proces rekonwalescencji i tym samym na poprawę sprawności językowych, w tym farmakoterapii, a także czynników psychicznych i środowiskowych [zob. Herzyk, 2005, s. 104-105].

Równolegle ze zjawiskiem spontanicznej poprawy na skutek wycofywania się przejściowych zakłóceń neurofizjologicznych w ostrej i podostrej fazie udaru dochodzi także do uruchomienia wczesnych procesów neuroplastycznych związanych z takimi zjawiskami, jak na przykład odmaskowanie istniejących, lecz wcześniej niemych 
funkcjonalnie połączeń, tworzenie się nowych synaps czy rozrost dendrytyczny [Polanowska, 2016, s. 17]. W przypadku zdrowienia samoistnego we wczesnym okresie po udarze zmiany plastyczne mają więc charakter restytucji, na którą dodatkowo mogą nakładać się jeszcze później zmiany kompensacyjne [zob. Drozdowski, 2007].

W odróżnieniu do samoistnych mechanizmów naprawczych, związanych z ustępowaniem zaburzeń o charakterze neurodynamicznym, druga grupa mechanizmów powrotu sprawności językowych po udarze jest już ściśle związana z trwałym, ogniskowym uszkodzeniem struktur nerwowych należących do dynamicznego układu funkcjonalnego danej czynności [zob. Panasiuk, 2014]. Na dalszym etapie zdrowienia zmiany funkcjonalne są odzwierciedleniem procesów kompensacyjnych mózgu, polegających na reorganizacji strukturalnej i funkcjonalnej obwodów neuronalnych (zob. rysunek 1). Jak pisze Anna M. Rajtar:

\footnotetext{
Utracone funkcje są odzyskiwane przez obszary mózgu anatomicznie bądź funkcjonalnie zbliżone do tych, które uległy niedokrwieniu. W zależności od lokalizacji i wielkości uszkodzenia procesy reintegracji mogą obejmować również obszary dystalne oraz kontrlateralne do miejsca uszkodzenia [Rajtar, 2012, s. 207].
}

Coraz częściej więc szczególną rolę w odzyskiwaniu utraconych funkcji językowych przypisuje się nie tylko obszarom lewej półkuli mózgu, ale także strukturom znajdującym się w półkuli prawej. W przypadku zachorowania udarowego możliwości naprawcze uszkodzonych układów neuronalnych zależą przede wszystkim od takich czynników, jak wielkość ogniska udaru, stopień zniszczenia układu funkcjonalnego oraz gęstość jego połączeń. Przyjmuje się, że minimalna rezerwa komórkowa potrzebna do zapoczątkowania procesu kompensacyjnego wynosi 15-20\% przetrwałych neuronów [Polanowska, 2016, s. 17].Z kolei objętość ogniska uszkodzenia w lewej półkuli mózgu przekraczająca $100 \mathrm{~cm} 3$ uważana jest za negatywny czynnik rokowniczy [Koenig-Bruhin i wsp., 2013, s. 292]. Przy częściowym lub całkowitym braku zdolności do regeneracji tkanki nerwowej bierze się jednak pod uwagę możliwość przełamywania występujących na skutek udaru zaburzeń językowych na drodze przebudowy układu funkcjonalnego (wewnątrzlub międzyukładowej) w myśl jednej z zasad modelu czynnościowego plastyczności, a mianowicie zasady zreorganizowania funkcji [zob. Panasiuk, 2014]. Dlatego też zarówno we wczesnym, jak i przewlekłym etapie rekonwalescencji pacjentów po udarze szczególną rolę we wspomaganiu procesów naprawczych niezmiennie przypisuje się oddziaływaniom neurorehabilitacyjnym, których celem jest usprawnienie i odbudowa utraconych czynności (ruchowych, językowych itp.) w możliwie jak największym zakresie [Seniów, Krawczyk, Członkowska, 2007]. 


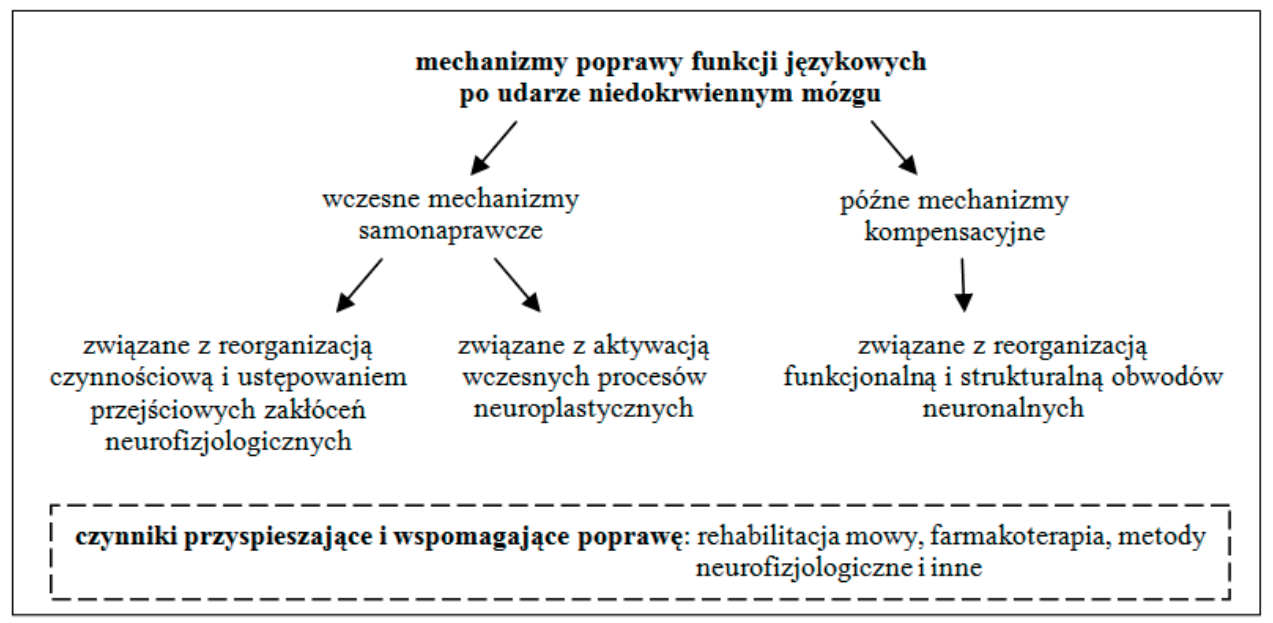

Rysunek 1. Potencjalne mechanizmy poprawy funkcji językowych po udarze niedokrwiennym mózgu

Źródło: opracowanie własne na podstawie Polanowska, 2016.

Podsumowując, należy podkreślić, że - z uwagi na brak jednoznacznych dowodów naukowych potwierdzających wyodrębnione zasady - zarówno modele fizjologiczne, jak i modele strukturalne nadal traktowane są jako niewystarczająco przekonujące [Panasiuk, 2014]. W odróżnieniu od modeli strukturalnych, wyjaśniających mechanizmy kompensacji w późniejszym okresie - od momentu uszkodzenia ośrodkowego układu nerwowego, to właśnie modele fizjologiczne postrzegane są jako te, które pozwalają tłumaczyć zjawiska obserwowane wyłącznie we wczesnej fazie zachorowania, czyli tuż po zaistnieniu czynnika patologicznego w mózgu. Pojawiające się wciąż ograniczenia, związane między innymi z niemożnością jednoznacznego zróżnicowania wpływów oddziaływań lekarskich (np. farmakoterapii) od mechanizmów samoistnej kompensacji mózgu, sprawiają, iż wchodzące w ich skład zasady nadal stanowią źródło licznych kontrowersji i są poddawane dyskusjom. Z perspektywy logopedycznej jako najbardziej adekwatną w interpretacji zdolności komunikacyjnych u chorych z uszkodzeniami mózgu niezmiennie wskazuje się dziś zasadę zreorganizowania funkcji, wchodzącą w skład modeli czynnościowych (przetwarzania) [zob. Panasiuk, 2014]. Opiera się ona na koncepcji Aleksandra R. Łurii [1976], według której wszystkie funkcje mózgowe są kontrolowane przez złożony system obszarów mózgu, tworzących różne funkcjonalne podukłady. W myśl tej zasady istnieje więc możliwość przejęcia danej funkcji przez inne, nieuszkodzone obszary w ośrodkowym układzie nerwowym, co daje nadzieję na skompensowanie utraconej sprawności [Pąchalska, 2011; Panasiuk, 2014]. 


\section{Metody i strategie wspierania odbudowy sprawności językowych u pacjentów z afazją poudarową}

Wiedza na temat zjawiska plastyczności ośrodkowego układu nerwowego u osób dorosłych stanowi dziś fundament w budowaniu skutecznych strategii oddziaływania rehabilitacyjnego wśród pacjentów z różnymi schorzeniami neurologicznymi. Cele terapii w przypadku chorych $\mathrm{z}$ afazją poudarową wyznacza przede wszystkim czas, jaki upłynął od momentu zachorowania [Seniów, Litwin, 2013, s. 50]. Biorąc pod uwagę fakt, że fazy zdrowienia różnią się między sobą mechanizmami sterującymi poprawą w zakresie sprawności językowych, w praktyce klinicznej również zachodzi konieczność wdrażania odmiennych strategii wspierających tę poprawę.

Znajomość mechanizmów neuroplastyczności, jak również świadomość oddziaływania tak zwanych czynników neurodynamicznych we wczesnym okresie zdrowienia, ułatwia dostosowanie metod diagnostycznych i terapeutycznych do aktualnych potrzeb i możliwości chorego. W przypadku terapii neurologopedycznej afazji zalecana jest więc dyferencjacja sposobów oddziaływania właśnie w zależności od fazy zdrowienia [zob. m.in. Maruszewski, 1974; Nowakowska, 1978; Panasiuk, 2008; 2015; Pąchalska, 2011]. Każda z faz różni się bowiem nie tylko mechanizmem dominujących objawów, ale także ich charakterystyką. Wśród metod neurolingwistycznych wspierających proces poprawy językowej u chorych $\mathrm{z}$ afazją wskazuje się najczęściej metody bezpośrednie, pośrednie oraz uprzedzania 5 (zob. tabela 2).

Tabela 2. Zróżnicowanie metod i celów terapii logopedycznej w zależności od fazy zdrowienia

\begin{tabular}{|c|c|c|}
\hline & $\begin{array}{l}\text { Faza wczesna } \\
<3 \text { miesięcy }\end{array}$ & $\begin{array}{c}\text { Faza przewlekła } \\
>3 \text { miesięcy }\end{array}$ \\
\hline \multirow{2}{*}{ Metody terapii } & $\begin{array}{l}\text { Metody rozhamowujące } \\
\text { Metody stymulujące }\end{array}$ & Metody bezpośrednie \\
\hline & \multicolumn{2}{|l|}{ Metody uprzedzania } \\
\hline Cele terapii & $\begin{array}{l}\text { Wspomaganie i przyspieszanie procesu } \\
\text { samoistnej poprawy } \\
\text { Zapobieganie niepożądanym objawom } \\
\text { psychogennym i nieprawidłowym } \\
\text { zachowaniom językowym }\end{array}$ & $\begin{array}{l}\text { Przełamanie głównego mechanizmu } \\
\text { zaburzeń językowych przez } \\
\text { przebudowę układu funkcjonalnego } \\
\text { dla mowy } \\
\text { Reintegracja społeczna chorego }\end{array}$ \\
\hline
\end{tabular}

Źródło: opracowanie własne na podstawie Maruszewski, 1974; Pąchalska, 2011; Panasiuk, 2015.

We wczesnym okresie zdrowienia, kiedy działają czynniki samoistnej kompensacji, a w obrazie klinicznym dominują objawy zmienne i nietrwałe, zaleca się

5 W literaturze przedmiotu obserwuje się subtelne rozbieżności w zakresie terminologii oraz sposobów charakteryzowania wyodrębnionych tu metod terapii [por. Maruszewski, 1974; Pąchalska, 2011; Panasiuk, 2015]. W niniejszej pracy autorka podejmuje próbę „pogodzenia” stanowisk, w głównej mierze bazując jednak na ujęciu zaproponowanym przez Jolantę Panasiuk [2008; 2015]. 
wdrażanie tak zwanych metod pośrednich (pobudzających) o charakterze rozhamowującym i stymulującym ogólną aktywność językową chorego ${ }^{6}$ [Panasiuk, 2008; 2015]. Celem postępowania logopedycznego jest w tym czasie wspieranie i przyspieszanie spontanicznego powrotu zablokowanych i zaburzonych czynności językowych, ale także zapobieganie występowaniu objawów niepożądanych dla chorego - tak w zakresie języka (np. powstawaniu stylu telegraficznego), jak i w zachowaniu (np. pojawieniu się logofobii lub zachowań agresywnych). O ile tym pierwszym mają służyć właśnie metody stymulacji i rozhamowania mowy, o tyle drugim metody uprzedzania, przeciwdziałające pojawieniu się nieprawidłowych nawyków językowych i zaburzeń psychogennych [por. Maruszewski, 1974; Panasiuk, 2015]. Mimo że rola metod uprzedzania wzrasta szczególnie we wczesnym okresie zdrowienia, to jednak z uwagi na często długotrwały, modyfikowany różnymi czynnikami proces rekonwalescencji chorych $\mathrm{z}$ afazją słuszne wydaje się również docenienie ich wartości na każdym $\mathrm{z}$ etapów terapii, $\mathrm{w}$ tym także $\mathrm{w}$ fazie przewlekłej. Równie ważna jest w tym czasie wnikliwa obserwacja pacjenta i uwrażliwienie na zmieniające się psychospołeczne aspekty jego funkcjonowania, które niemal w każdym momencie mogą przyczynić się do wyzwolenia niepożądanych objawów.

Wraz ze stabilizacją stanu klinicznego pacjenta, związaną najczęściej z wycofaniem się symptomów neurodynamicznych i tym samym ujawnieniem tak zwanego defektu podstawowego (czyli mechanizmu zaburzeń językowych), wskazane jest z kolei koncentrowanie uwagi na przełamywaniu trwałych zaburzeń językowych przez wykorzystanie zróżnicowanych metod analitycznych mających na celu przebudowę układu funkcjonalnego dla mowy [Panasiuk, 2008; 2015]. Szczególną rolę przypisuje się tu metodom bezpośrednim, ukierunkowanym na ćwiczenie ściśle określonych czynności językowych, które w wyniku uszkodzenia mózgu zostały zaburzone [por. Maruszewski, 1974; Pąchalska, 2011; Panasiuk, 2015]. Jak podkreśla Jolanta Panasiuk [2015, s. 908], metody te sprawdzają się w przypadku osób, u których - ze względu na cechy lateralizacji, wiek oraz płeć - przewiduje się możliwość przejęcia zaburzonych funkcji przez nieuszkodzoną półkulę lub gdy stwierdza się istnienie rezerwowych możliwości w zakresie ćwiczonej funkcji. Istotną rolę może odgrywać tu tak zwany specyficzny trening językowy (Language Impairment-Based Therapy - LIBT), polegający na wprowadzeniu ćwiczeń bezpośrednio ukierunkowanych na dominujący deficyt (fonologiczny, semantyczny, leksykalny syntaktyczny) [Polanowska, 2016]. Dzięki niemu istnieje możliwość odbudowania funkcji

6 Metody rozhamowujące bazują na zautomatyzowanej aktywności werbalnej chorego (np. umiejętności przedstawienia się czy wymieniania nazw miesięcy lub dni tygodnia), która w dalszej kolejności ma przyczynić się do rozwoju kontrolowanych i dowolnych zachowań językowych. Metody stymulujące opierają się natomiast na specjalnie dobranym materiale językowym, który ma pobudzać chorego do mówienia, na przykład przez wywołanie określonych emocji. Służyć temu mogą ćwiczenia koncentrujące się bezpośrednio na zainteresowaniach pacjenta lub jego cechach osobowościowych [Panasiuk, 2008; 2015]. 
lub jej ponownego wyuczenia. Wprowadzenie specyficznego treningu językowego zalecane jest wtedy, gdy stan kliniczny pacjenta jest już względnie ustabilizowany, a proces zdrowienia cechuje pewien stopień przewidywalności [Seniów, Litwin, 2013]. Czas trwania uzależniony jest od postępów, co oznacza, iż zakłada się możliwość kontynuowania treningu tak długo, jak długo obserwuje się pozytywną zmianę w zakresie sprawności językowych i komunikacyjnych chorego ${ }^{7}$. Wśród znanych zagranicznych metod w ramach specyficznego treningu językowego wymienia się na przykład metodę HELPSS (Helm Elicited Program for Syntax Stimulation) [Helm-Estabrooks, 1981] oraz terapię melodyczno-intonacyjną (Melodic Intonation Therapy) [Sparks, Helm, Albert, 1974], które służą usprawnianiu syntaktycznego aspektu języka u pacjentów z niewielką afazją motoryczną [za: Seniów, 2009]. W polskiej literaturze afazjologicznej na szczególną uwagę zasługują przede wszystkim ćwiczenia proponowane przez Jolantę Panasiuk w ramach programu terapii logopedycznej zaburzeń mowy w poszczególnych typach afazji według klasyfikacji Łuriowskiej [zob. Panasiuk, 2015]. Zdaniem badaczki podstawową zasadą w reorganizacji zaburzonych czynności językowych jest przełamywanie mechanizmu obserwowanych objawów zaburzeń językowych w oparciu o zachowane elementy dynamicznego „łańcucha mowy" [Panasiuk, 2015, s. 909]. Na przykład w przypadku afazji motorycznej kinetycznej będą to ćwiczenia przełamujące podstawowy defekt w postaci zaburzeń syntezy sekwencyjnej, natomiast w przypadku afazji akustyczno-gnostycznej ćwiczenia przełamujące zaburzenia słuchu fonematycznego.

Biorąc pod uwagę powyższe metody oddziaływania logopedycznego i ich zastosowanie w zależności od fazy zdrowienia, można wyodrębnić - za Walterem Huberem i jego współpracownikami [1993] - trzy główne etapy w procesie terapii pacjentów z afazją poudarową [za: Seniów, 2009, s. 30]:

1) etap ogólnej aktywizacji językowej,

2) etap specyficznego usprawniania,

3) etap utrwalania zdobytych umiejętności i/lub kompensowania trudności8.

Należy jednak dodać, że granice wykorzystania poszczególnych metod w zależności od fazy zdrowienia są płynne. Ich wdrażanie warunkowane jest nie tylko czynnikiem czasu, ale także takimi aspektami, jak rozległość uszkodzenia obszaru mowy, stopień zaburzeń afatycznych, ogólny stan kliniczny i psychiczny chorego. Nie należy

7 Warto podkreślić za Marią Pąchalską [2007, s. 108], iż terapia prowadzona wyłącznie na podstawie analizy deficytów specyficznie językowych niekoniecznie musi przynieść wymierne korzyści dla pacjentów pod względem ich funkcjonowania społecznego. Szczególnie ważne jest więc również zwrócenie uwagi na role społeczne, które chorzy muszą spełniać na co dzień w środowisku.

$8 \mathrm{~W}$ ramach etapu trzeciego, związanego z utrwalaniem sprawności, inny badacz - Luise Springer [2008] - postuluje uwzględnienie terapii, której celem jest także reintegracja społeczna pacjentów z afazją poudarową [za: Daniluk, 2017]. M. Pąchalska [2011, s. 216] formułuje natomiast dwa nadrzędne cele rehabilitacji chorych $\mathrm{z}$ afazją: 1) reintegrację psychiczną, polegającą na odbudowie utraconej zdolności porozumiewania się językowego, 2) reintegrację społeczną, polegającą na poprawie jakości życia pacjentów i możliwości powrotu do pracy. 
wykluczać tym samym możliwości „przetasowania” metod w zależności od indywidualnych potrzeb i możliwości pacjenta.

Praktyka kliniczna potwierdza, że zachodzące w uszkodzonym mózgu zmiany plastyczne - dodatkowo wspomagane czynnikami zewnętrznymi zarówno w postaci specyficznego treningu językowego, jak i niespecyficznej stymulacji - mogą przyczynić się do funkcjonalnej reorganizacji mózgu9. Współcześnie, dzięki zastosowaniu metod funkcjonalnego mapowania kory mózgowej (np. przezczaszkowej stymulacji magnetycznej, funkcjonalnego rezonansu magnetycznego, magnetoencefalografii), istnieje możliwość prześledzenia procesu czynnościowego przeorganizowania się mózgu w wyniku treningu określonych sprawności. Badacze dowodzą równocześnie, że intensywny trening może doprowadzić także do zmian strukturalnych w obszarze związanym $\mathrm{z}$ trenowanymi funkcjami i nie dotyczy to wyłącznie osób z uszkodzeniem mózgu ${ }^{10}$. Według Anny Grabowskiej [2016, s. 23] mózg działa według zasady: „use it or lose it” ('używaj albo trać). Jeśli z jakichś przyczyn dane miejsce nie otrzymuje stymulacji, wówczas natychmiast zaczyna się proces inwazji miejsc sąsiednich na to, które nie jest wykorzystywane. W mózgu nie istnieją zatem nieme i nieczynne miejsca [Grabowska, 2016].

Rola stymulacji i ponownego uczenia się odgrywa w procesie rehabilitacji chorych $\mathrm{z}$ afazją kluczową rolę. Mimo że intensywność i czas trwania terapii logopedycznej powinien być dostosowany do fazy choroby i indywidualnych uwarunkowań kliniczno-społeczno-psychologicznych pacjenta, to jednak wciąż zaleca się jak najwcześniejsze jej wdrażanie [zob. Robey, 1998; Laska i wsp., 2011; Godecke i wsp., 2012]. Jak pisze Katarzyna Polanowska:

Wczesna stymulacja może zatem chronić przed niekorzystnymi zmianami neuroplastycznymi, wynikającymi z braku aktywowania przetrwałych obwodów neuronalnych, które są odpowiedzialne za zaburzone funkcje [Polanowska, 2016, s. 19].

W przypadku pacjentów z afazją poudarową we wczesnej fazie zdrowienia wybór strategii oddziaływania terapeutycznego podyktowany jest wieloma czynnikami. Oprócz czynników biologicznych, determinujących typ afazji, głębokość i ewentualną trwałość zaburzeń, szczególną rolę odgrywają tu również czynniki zewnętrzne,

9 Szczególną rolę przypisuje się tu nie tylko oddziaływaniom farmakologicznym przyspieszającym proces zdrowienia, ale także metodom eksperymentalnej stymulacji kory mózgowej, takim jak przezczaszkowa stymulacja magnetyczna (rTMS), przezczaszkowa bezpośrednia stymulacja prądem stałym (tDCS) czy bodźcowanie somatosensoryczne. W ostatnim czasie w terapii chorych $\mathrm{z}$ afazją wskazuje się również na pozytywne efekty tzw. terapii wymuszonej koniecznością (constrained-induced therapy), która pierwotnie wykorzystywana była w rehabilitacji jednostronnych niedowładów kończyn [Seniów, 2009].

10 Na przykład badania londyńskich taksówkarzy wykazały, że tylna część hipokampa jest u nich większa niż u osób z grupy kontrolnej. 
związane między innymi ze stanem psychicznym chorego (np. poziomem motywacji), ale także z jego uwarunkowaniami środowiskowymi (np. statusem rodzinnym). Wiedza na temat tego, czy pacjent $\mathrm{z}$ afazją ma rodzinę, która będzie w stanie zapewnić mu po wyjściu ze szpitala dalszą opiekę specjalistyczną (w tym kontynuację terapii), ale także świadomie uczestniczyć w procesie terapeutycznym, może okazać się cenną wskazówką w doborze strategii oddziaływania logopedycznego już w początkowej fazie rehabilitacji. Ponieważ powyższe czynniki niejako determinują możliwe dalsze losy chorego, już we wczesnym etapie zachorowania należy dokonać wstępnego wyboru metod i strategii terapii, nie wykluczając oczywiście przy tym możliwości ich modyfikacji, między innymi z uwagi na silne oddziaływanie w tym czasie czynników o charakterze neurodynamicznym. Biorąc jednak pod uwagę fakt, iż pacjent po wyjściu z oddziału udarowego ma kilka potencjalnych dróg dalszego funkcjonowania (wypis: do domu ze skierowaniem do poradni logopedycznej lub bez skierowania, do oddziału rehabilitacji, do zakładu opiekuńczo-leczniczego, do domu pomocy społecznej), należy rozważyć możliwość wyboru odpowiedniego sposobu postępowania logopedycznego w ramach następujących strategii wyodrębnionych przez Mariusza Maruszewskiego [1974]:

1) maksymalistycznej - zakładającej możliwość pozostawania chorego pod fachową opieką tak długo, jak będzie wymagał tego proces terapii;

2) realistycznej - zakładającej, że chory nie będzie miał możliwości kontynuacji terapii, a przewidywany okres rehabilitacji jest niewystarczający do zlikwidowania wszystkich trudności językowych;

3) minimalistycznej - zakładającej, że jedyną formą terapii dla chorego, z uwagi na głębokość prezentowanych zaburzeń i brak pomyślnego rokowania, jest wykorzystanie zastępczych metod komunikacji słownej, które zapewnią choćby minimum kontaktu $\mathrm{z}$ otoczeniem.

Jako że, zgodnie z zasadami współczesnej rehabilitacji pacjentów po udarze mózgu, każdy chory już od początku hospitalizacji powinien być traktowany w taki sposób, jak gdyby miał w pełni odzyskać utracone funkcje, należy zrezygnować $\mathrm{z}$ wdrażania we wczesnym etapie zdrowienia od razu strategii o charakterze kompensacyjnym i minimalistycznym [zob. Nyka, Jankowska, 2009, s. 87]. Wybór metod i strategii wspierania odbudowy sprawności językowych pacjentów po udarze mózgu powinien być przede wszystkim podyktowany dobrem pacjenta, jego wydolnością psychofizyczną i aktualnymi potrzebami, determinowanymi nie tylko czynnikami biologicznymi, ale także uwarunkowaniami psychicznymi i środowiskowymi. Również intensywność i czas trwania ćwiczeń powinien być dostosowany do indywidualnych możliwości chorego w danym dniu. Nabiera to szczególnego znaczenia zwłaszcza we wczesnej fazie udaru, kiedy jego stanem klinicznym rządzą przede wszystkim czynniki neurodynamiczne. 
Literatura

Daniluk Beata 2017, Afazja, [w:] Z. Tarkowski (red.), Patologia mowy, Gdańsk: Harmonia Universalis, s. 39-80.

Drozdowski Wiesław, 2007, Neuroplastyczność - nadzieja w terapii chorób układu nerwowego, „Neurologia Praktyczna”, t. VII, nr 4(37), s. 9-15.

Godecke Erin, Hird Kathryn, Lalor Erin E., Rai Tapan, Phillips Michael R., 2012, Very early poststroke aphasia therapy: a pilot randomized controlles efficacy trial, „International Journal of Stroke", no. 7, s. 635-644.

Grabowska Anna, 2016, Plastyczny mózg - „używaj albo trać”, „Wszechświat. Pismo Przyrodnicze”, t. 117 , nr 1-3, s. 20-28.

Helm-Estabrooks Nancy, 1981, Elicited Program for Syntax Stimulation, Austin: PRO-ED.

Herzyk Anna, 2005, Wprowadzenie do neuropsychologii klinicznej, Warszawa: Wydawnictwo Naukowe „Scholar”.

Huber Walter, Springer Luise, Willmes Klaus, 1993, Approaches to aphasia therapy in Aachen, [w:] A. Holland, F. Forbes (red.), Aphasia treatment. World perspectives, San Diego: Singular Publishing Group, s. 55-86.

Koenig-Bruhin Monica, Kolonko Beate, At Ayse, Annoni Jean-Marie, Hunziker Erika, 2013, Aphasia following a stroke: Recovery and recommendations for rehabilitation, „Swiss Archives of Neurology and Psychiatry", no. 164(8), s. 292-298.

Kossut Małgorzata, 2005, Neuroplastyczność, [w:] T. Górska, A. Grabowska, J. Zagrodzka (red.), Mózg a zachowanie, Warszawa: Wydawnictwo Naukowe PWN, s. 590-613.

Kossut Małgorzata, 2010, Synapsy i plastyczność mózgu, [w:] oprac. zbiorowe, Polskie i światowe osiagnięcia nauki. Nauki biologiczne, Gliwice: Wydawnictwo Fundacja im. Wojciecha Świętosławskiego na rzecz Wspierania Nauki i Rozwoju Potencjału Naukowego w Polsce, s. 285-305.

Krajewska Małgorzata, 2015, Obraz afazji na tle procesów neurodynamicznych w ostrej fazie udaru - na przykładzie studium przypadku pacjentki z krwiakiem śródmózgowym lewej półkuli mózgu, „Neurolingwistyka Praktyczna”, nr 1, s. 125-139.

Krajewska Małgorzata, 2016/2017, Dynamika i obraz afazji we wczesnej fazie udaru niedokrwiennego. Opis przypadku, „Biuletyn Logopedyczny”, nr 1-2(30-31), s. 97-117.

Książkiewicz Barbara, Gąsecki Dariusz, 2004, Leczenie we wczesnym okresie udaru, [w:] R. Mazur, B. Książkiewicz, W.M. Nyka (red.), Udar mózgu w praktyce lekarskiej, Gdańsk: Wydawnictwo Via Medica, s. 67-89.

Laska Ann Charlotte, Kahan Thomas, Hellblom Anders, Murray Veronica, Arbin Magnus von, 2011, A randomized controlled trial on very early speech and language therapy in acute stroke patients with aphasia, „Cerebrovascular Diseases Extra”, no. 1(1), s. 66-74.

Litwin Tomasz, Członkowska Anna, 2014, Ostre niedokrwienie mózgu - udar niedokrwienny i przemijające niedokrwienie mózgu, [w:] A. Stępień (red.), Neurologia, t. 2, Warszawa: Wydawnictwo Medical Tribune Polska, s. 189-215.

Łuria Aleksander R., 1976, Podstawy neuropsychologii, przeł. D. Kądzielawa, Warszawa: Państwowy Zakład Wydawnictw Lekarskich.

Maruszewski Mariusz, 1974, Chory z afazja i jego usprawnianie, Warszawa: Wydawnictwo Nasza Księgarnia.

Nowakowska Maria T. (red.), 1978, Rehabilitacja chorych z afazja, Wrocław: Zakład Narodowy im. Ossolińskich.

Nyka Wiesław, Jankowska Bożena, 2009, Zasady wczesnej rehabilitacji chorych z udarem niedokrwiennym mózgu, „Forum Medycyny Rodzinnej”, t. 3, nr 2, s. 85-91. 
Panasiuk Jolanta, 2008, Standard postępowania logopedycznego w afazji, „Logopedia”, t. 37, s. $255-279$.

Panasiuk Jolanta, 2014, Terapia zaburzeń mowy u chorych neurologicznie a mechanizmy neuroplastyczności, [w:] M. Michalik (red.), Nowa Logopedia, t. 5, Kraków: Wydawnictwo Collegium Columbinum, s. 41-65.

Panasiuk Jolanta, 2015, Postępowanie logopedyczne w przypadkach afazji, [w:] S. Grabias, J. Panasiuk, T. Woźniak (red.), Logopedia. Standardy postępowania logopedycznego. Podręcznik akademicki, Lublin: Wydawnictwo Uniwersytetu Marii Curie-Skłodowskiej, s. 869-916.

Papathanasiou Ilias, 2003, Nervous system mechanisms of recovery and plasticity following injury, „Acta Neuropsychologica”, no. 1(3), s. 345-354.

Paradowski Bogusław, Pawlik Barbara, 2005, Zjawisko diaschizy w różnych chorobach układu nerwowego, „Wiadomości Lekarskie”, t. LVIII, nr 11-12, s. 575-677.

Pąchalska Maria, 2007, Neuropsychologia kliniczna. Urazy mózgu, t. 2, Warszawa: Wydawnictwo Naukowe PWN.

Pąchalska Maria, 2008, Rehabilitacja neuropsychologiczna. Procesy poznawcze i emocjonalne, Lublin: Wydawnictwo Uniwersytetu Marii Curie-Skłodowskiej.

Pąchalska Maria, 2011, Afazjologia, Warszawa: Wydawnictwo Naukowe PWN.

Pąchalska Maria, Kaczmarek Bożydar L.J., Kropotov Juri D., 2014, Neuropsychologia kliniczna. Od teorii do praktyki, Warszawa: Wydawnictwo Naukowe PWN.

Polanowska Katarzyna E., 2016, Mechanizmy odbudowy funkcji językowych po udarze mózgu, „Neurologia po Dyplomie”, t. 11, nr 2, s. 16-23.

Powell Graham E., 1981, Brain function therapy, Aldershot: Gower.

Rajtar Anna M., 2012, Zastosowanie przezczaszkowej stymulacji magnetycznej w modulowaniu mechanizmów neuroplastyczności po udarze niedokrwiennym mózgu, „Neuropsychiatria i Neuropsychologia", nr 7(4), s. 206-211.

Rejdak Konrad, 2007, Strategie neuroprotekcyjne w postępowaniu z pacjentem $z$ udarem niedokrwiennym mózgu, „Neurologia Praktyczna”, t. VII, nr 5(38), s. 8-14.

Robertson Ian H., Murre Jaap M., 1999, Rehabilitation of brain damage: Brain plasticity and principles of guided recovery, „Psychological Bulletin”, no. 125(5), s. 544-575.

Robey Randall R., 1998, A meta-analysis of clinical outcomes in the treatment of aphasia, „Journal of Speech, Language and Hearing Research", no. 41(1), s. 172-187.

Rymarczyk Krystyna, Makowska Iwona, Pałka-Szafraniec Katarzyna, 2015, Plastyczność dorosłej kory mózgowej, „Aktualności Neurologiczne”, nr 15(2), s. 80-87.

Seniów Joanna, 2009, Proces zdrowienia chorych $z$ afazja poudarowa w kontekście współwystępujących nielingwistycznych dysfunkcji poznawczo-behawioralnych, Warszawa: Wydawnictwo Instytutu Psychiatrii i Neurologii.

Seniów Joanna, Krawczyk Maciej, Członkowska Anna, 2007, Rehabilitacja chorych po udarze mózgu, [w:] A. Szczudlik, A. Członkowska, H. Kwieciński, A. Słowik (red.), Udar mózgu, Kraków: Wydawnictwo Uniwersytetu Jagiellońskiego, s. 275-285.

Seniów Joanna, Litwin Marika, 2013, Afazja poudarowa, „Neurologia po Dyplomie”, nr 8(2), s. $46-51$.

Sparks Robert, Helm Nancy, Albert Martin, 1974, Aphasia rehabilitation resulting from Melodic Intonation Therapy, „Cortex”, no. 10, s. 303-316.

Springer Luise, 2008, Therapeutic approaches in aphasia rehabilitation, [w:] B. Stemmer,

H.A. Whitaker (red.), Handbook of the Neuroscience of Language, London: Elsevier, s. 397-406.

Turowska-Kowalska Jolanta, Nowacki Przemysław, 2013, Objawy błędnie lokalizujace w neurologii, „Polski Przegląd Neurologiczny”, t. 9, nr 3, s. 120-124.

Wnuk Marcin, Słowik Agnieszka, 2016, Udar mózgu na dyżurze, Poznań: Wydawnictwo Termedia. 
Streszczenie

Odkrycie zjawiska plastyczności dojrzałego układu nerwowego stało się nadzieją w procesie neurorehabilitacji pacjentów z różnymi uszkodzeniami mózgu, w tym w terapii logopedycznej pacjentów z afazją poudarową. Jako że udar niedokrwienny mózgu jest aktualnie najczęstszą przyczyną afazji wśród osób dorosłych, artykuł jest prezentacją potencjalnych mechanizmów poprawy sprawności językowych właśnie po udarze niedokrwiennym.

\section{Summary}

The discovery of the phenomenon of mature nervous system plasticity has become a hope in the process of neurorehabilitation of patients with various brain injuries, including speech therapy in patients with poststroke aphasia. Because an ischemic stroke is currently the most common cause of aphasia in adults, the article is the presentation of potential mechanisms of language skills improvement in the course of a stroke. 